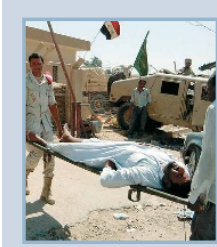

p110 Public health

in peril: War has

decimated Iraq's

research and health

systems

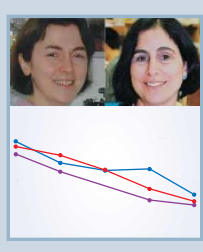

p114 A woman's

place: Female

scientists are still

struggling to find a

foothold

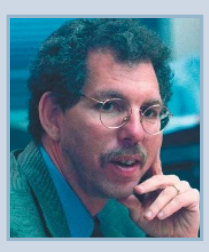

p116 Fat chance:

Luck and leptin

have brought fame

and fortune to

Jeff Friedman

\title{
US pressures publishers to honor trade embargoes
}

A US government agency better known for seizing the assets of dope smugglers has become an arbiter of scientific publishing. Bowing to pressure from the Office of Foreign Assets Control (OFAC), a branch of the US Treasury Department, the American Society for Microbiology (ASM) on 12 January stopped accepting papers submitted to its 11 journals from Sudan, Libya, Iran and Cuba.

The OFAC monitors and enforces the US trade embargo against the countries. The federal regulations that define the terms of the embargo specifically exempt journal articles and other forms of communication, but only if they are finished works.

According to R. Richard Newcomb, director of the OFAC, reviewing and editing are considered "services," which are prohibited if an author, editor or reviewer is affiliated with an embargoed country. A manuscript submitted in camera-ready form is legal, but if edited by the recipient-even if the changes go no further than copy-editing-it is not. Scientific manuscripts are typically passed back and forth between author, editor and reviewer, with changes occurring at each transit, until a final version is hammered out.

The OFAC provides a licensing mechanism allowing editors to apply for permission to publish, but the process is cumbersome and time consuming. In one case, it took 10 months for the agency to respond to a license request for a paper from Iran.

Following a letter from the OFAC in September 2003, the Institute of Electrical and Electronics Engineers has chosen to reject all but camera-ready manuscripts from the embargoed countries. The American Chemical Society also no longer accepts submissions from those countries.

Sam Kaplan, chair of the publications board of the ASM, says his society will apply for OFAC licenses, and will try to initiate legislation to exempt scientific exchange entirely. For the time being, however, the ASM reluctantly refuses submissions from the four countries.
"We are deeply distressed to take this action, but we cannot place our staff or volunteers in a position of jeopardy," Kaplan says. "We sincerely hope that knowledgeable people will appreciate the harm that this does to the scientific enterprise."

Other editors are also unhappy with the policy. "It's open discrimination not only against research but against people from certain countries," says Keith Yamamoto, editor of Molecular Biology of the Cell. "First Amendment issues aside, it smacks of ethnicism and doesn't have anything to do with science per se. I find it wildly inappropriate and embarrassing."

Yamamoto, who is a member of the Joint Steering Committee for Public Policy, a consortium of five learned societies that interfaces with members of Congress, says he will urge the group to oppose the OFAC licensing scheme. "For our government to be taking a stand against open scientific communication is very troubling," he says.

Potter Wickware, San Francisco

\section{Animal research stance spells knight-mare for Blakemore}

A fight has erupted in the UK over a leaked Cabinet Office document that suggests Colin Blakemore, the new chief executive of the Medical Research Council (MRC), was not recommended for knighthood because of his public support for animal research.

Heads of the MRC are typically granted knighthood. However, the document, leaked on 14 December, revealed that Blakemore had been rejected because of his "controversial work on vivisection." The document said Blakemore, an eminent neuroscientist who took on the new post in October, could be reconsidered if his reputation improved after his move to the MRC.

Blakemore has threatened to resign from his post, and says he has consistently spoken out in favor of animal research at considerable risk to himself and his family. Two letter bombs have been sent to Blakemore's home and, until recently, he had to travel with a police escort.

"My protest about the content of the leaked minutes has nothing to do with whether I deserve an honor," Blakemore says. "My expres- sions of concern have to do with the apparent inconsistency of government attitude to the use of animals in medical research."

Blakemore says he had planned new mechanisms to reward MRC-funded scientists for contributions to public communication. But the leak presents him with a dilemma, he says. "How can I write to MRC scientists to ask them to engage in public dialogue on animal experimentation in view of this evidence that, in

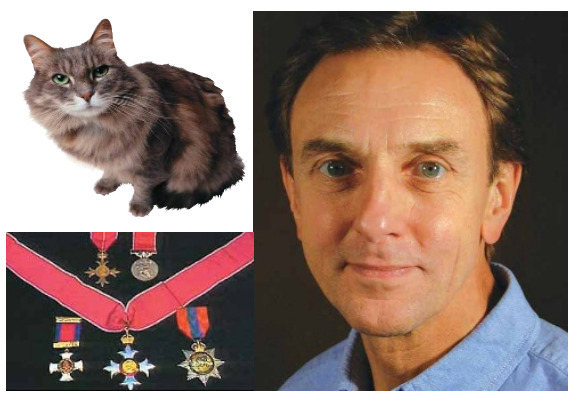

Colin Blakemore's support of animal research may have cost him knighthood. secret, their reputations will be damaged by doing so?" Blakemore says the government's stance on animal research is due to the substantial donations the Labour Party has received from animal liberation groups.

Not surprisingly, those groups are delighted that Blakemore was denied knighthood. Blakemore "had what can only can be described as a tantrum over the knighthood issue," says Andrew Tyler, director of Animal Aid. "Blakemore should either adjust his thinking or resign his position."

But several scientists and organizations are rallying around Blakemore. The new council of the Biosciences Federation, which has more than 60,000 members, has written to Prime Minister Tony Blair to ask him for a statement.

Calls for the honors system to be changed have also skyrocketed. The government has promised a review, and the system is also to be examined by the Commons Public Administration Committee.

Xavier Bosch, Barcelona 